\title{
The effect of washing procedure on the estimation of the in situ disappearance of amino acids from feed protein
}

\author{
G. HOF ${ }^{1}$, W. J. A. KOUWENBERG ${ }^{2} \&$ S. TAMMINGA ${ }^{1}$ \\ 1 Department of Animal Nutrition, Wageningen Agricultural University, Haagsteeg 4, \\ NL 6708 PM Wageningen, Netherlands \\ 2 Present adress: Sondervick 99, NL 5505 NC Veldhoven, Netherlands
}

Received 7 September 1989; accepted 26 June 1990

\begin{abstract}
In a small scale experiment the in-situ disappearance of amino acids and microbial contamination of the incubation residues were studied to investigate the influence of rumen incubation on the amino acid profile. Wilted grass silage, soybean expeller and hydrolysed feathermeal were used for the purpose. Incubation time ranged from zero till $48 \mathrm{~h}$. Three washing procedures were compared: a) standard procedure, b) standard washing, followed by soaking for $16 \mathrm{~h}$ in ND at $70^{\circ} \mathrm{C}$, followed by standard washing and c) a comparable procedure but using a ND solution at $25^{\circ} \mathrm{C}$. The amino acid profile appeared to be almost exclusively determined by amino acid content in the original feed. Amino acids disappeared at a faster rate than non-amino acid N. Microbial contamination was only observed in the grass silage and its residues after incubation. Non of the washing procedures removed effectively the contamination.
\end{abstract}

Keywords: protein degradation, in situ measurement, microbial contamination, washing procedure

\section{Introduction}

The response of ruminants to feed protein basically depends on the amount and nature of amino acids absorbed from the small intestine. This amount is usually estimated from the fraction of dietary protein escaping microbial degradation in the rumen, microbial protein synthesis in the rumen and the digestibility of both fractions. At present such predictions presume no difference in amino acid composition between the protein originally present in the feed and that escaping microbial degradation. Hence, the amino acid profile is not predicted correctly, if protein components differ in amino acid composition and rumen degradability.

The nylon bag technique is a widely accepted method for estimating the proportion of protein escaping rumen degradation (Mehrez \& Orskov, 1977). Sometimes the feed residues after incubation are contaminated with microbial protein, which results in an underestimation of protein degradation (Nocek, 1987). The prediction 
of the release of individual amino acids from feed protein with the in situ technique may be even more biased by microbial contamination when amino acid profile of the feed differs considerably from that of microbial protein.

Van Soest (1983) suggests that microbial contamination in digestive residues can be eliminated by washing with Neutral Detergent (ND). Boiling the residue in ND may not only remove microbial contamination, but also part of the insoluble feed protein. Therefore a milder treatment with ND at room temperature may be preferably.

In a small scale experiment the in situ disappearance of amino acids and microbial contamination of the incubation residues were studied in three feeds. The objectives of the experiment were:

- to estimate possible differences between the amino acid profile of residues after rumen incubation and of the original feed protein,

- to quantify microbial contamination in feed residue,

- to evaluate washing procedures on their effectiveness to eliminate microbial contamination.

\section{Experimental procedures}

Amino acid disappearance from nylon bags, suspended in the rumen of rumen cannulated dairy cows and containing wilted grass silage, soybean expeller or hydrolyzed feathermeal was measured according to a standardized procedure (Tamminga et al., 1989). Wilted grass silage was chosen as an example of feeds with a moderate protein content, which may partly be protected from degradation in the rumen because of its inclusion in cell walls. Feathermeal, on the other hand, is an example of feedstuffs with virtually no cell walls. Soybean meal combines a fairly high protein content with a moderate level of cell walls. Fresh grass silage was chopped to an average particle size of approximately $1 \mathrm{~cm}$, the other feeds were ground over a screen with $1 \mathrm{~mm}$ pore size. Rumen incubation times of soybean meal were 0,3 , 6 and 12 hours, those of grass silage and feathermeal 0, 6, 24 and 48 hours.

Three washing procedures were compared on their effect on amino acid content in the residues and on their effectiveness in the removal of microbes from the incubation residues:

a. standard procedure, using a domestic washing machine with cold water and no spinning (Tamminga et al., 1989),

b. washing according to (a), followed by soaking for $16 \mathrm{~h}$ in ND at $70^{\circ} \mathrm{C}$ (Geuring \& van Soest, 1979), followed by standard washing,

c. as (b), but ND temperature at $25^{\circ} \mathrm{C}$.

Feed and incubation residues were analysed for dry matter (ISO 6496), nitrogen (ISO 5983), ash (ISO 5989), amino acids and diaminopimelic acid (DAPA) content (Stadler \& Tanner, 1984).

The data were statistically analysed (SAS, 1985) according to the following model:

$$
y_{i j k l}=u+f_{i}+w_{j}+t_{k}+\text { two-way interactions }+e_{i j k l}
$$


where:

$y_{i j k l}=$ characteristic of the $i j k l^{\text {th }}$ residue

$u=$ overall mean

$f_{i}=$ effect of the $i^{\text {th }}$ feed

$w_{j}=$ effect of the $j^{\text {th }}$ washing procedure

$t_{k}=$ effect of the $k^{\text {th }}$ incubation time

$e_{i j k l}=$ error term

\section{Results and discussion}

Feathermeal had the highest proportion of amino acids per 16 gram $\mathrm{N}$ and grass silage the lowest (Table 1). The amino acid content in the three feedstuffs seem to be relatively low, however, histidine, phenylalanine, tyrosine and tryptophane were not measured. Corrected for these missing amino acids by using values from feed tables (CVB, 1988) the amino acids in soybean meal and feathermeal represented 96 and $90 \%$ of the expected values, respectively.

Individual amino acids disappeared at a slightly different rate, especially in soybean meal (Fig. 1). However, the differences were small and usually within the limits of analytical accuracy. In both concentrates the rate of amino acid disappearance was not much different from that of total protein. The disappearance of amino acids from grass silage protein was significantly higher than that of total protein after 24 hours incubation onwards. Table 1 shows for grass silage a lower proportion of amino acid $\mathrm{N}$ as compared to the other two feeds. The insoluble non-amino acid $\mathrm{N}$ in forage is assumed to be associated with the lignocellulosic complex (van Soest, 1983) and therefore released at a slower rate.

DAPA was only found in grass silage, which contained $0.349 \mathrm{~g}$ DAPA $\mathrm{N}$ per 100 $\mathrm{g} \mathrm{N}$ in the original feed (Fig. 1). Assuming $0.6 \mathrm{~g}$ DAPA $\mathrm{N}$ per $100 \mathrm{~g}$ microbial protein $\mathrm{N}$ (Nikolic \& Jovanovic, 1973), about $58 \%$ of the $\mathrm{N}$ in the silage would be of microbial origin. This is considerably more than usually found in grass silages (Rooke et al., 1984; Ullrich, 1984). Intensive lysis during the ensiling proces, or an inseparable co-eluting compound present in the silage (Crooker et al., 1987) may be responsible for this.

Table 1. Average amino acid in grams/16 grams $\mathrm{N}$ in feed and after incubation (standard washing procedure a).

\begin{tabular}{lclc}
\hline & Grass silage & Soybean meal & Hydrolysed feathermeal \\
In feed & 67.9 & 84.5 & 86.3 \\
After incubation & & & \\
$0 \mathrm{~h}$ & 70.2 & 81.6 & 87.4 \\
$3 \mathrm{~h}$ & - & 82.2 & - \\
$6 \mathrm{~h}$ & 71.6 & 82.9 & 90.2 \\
$12 \mathrm{~h}$ & - & 82.4 & - \\
$24 \mathrm{~h}$ & 66.9 & - & 90.6 \\
$48 \mathrm{~h}$ & 64.9 & - & 86.8 \\
\hline
\end{tabular}



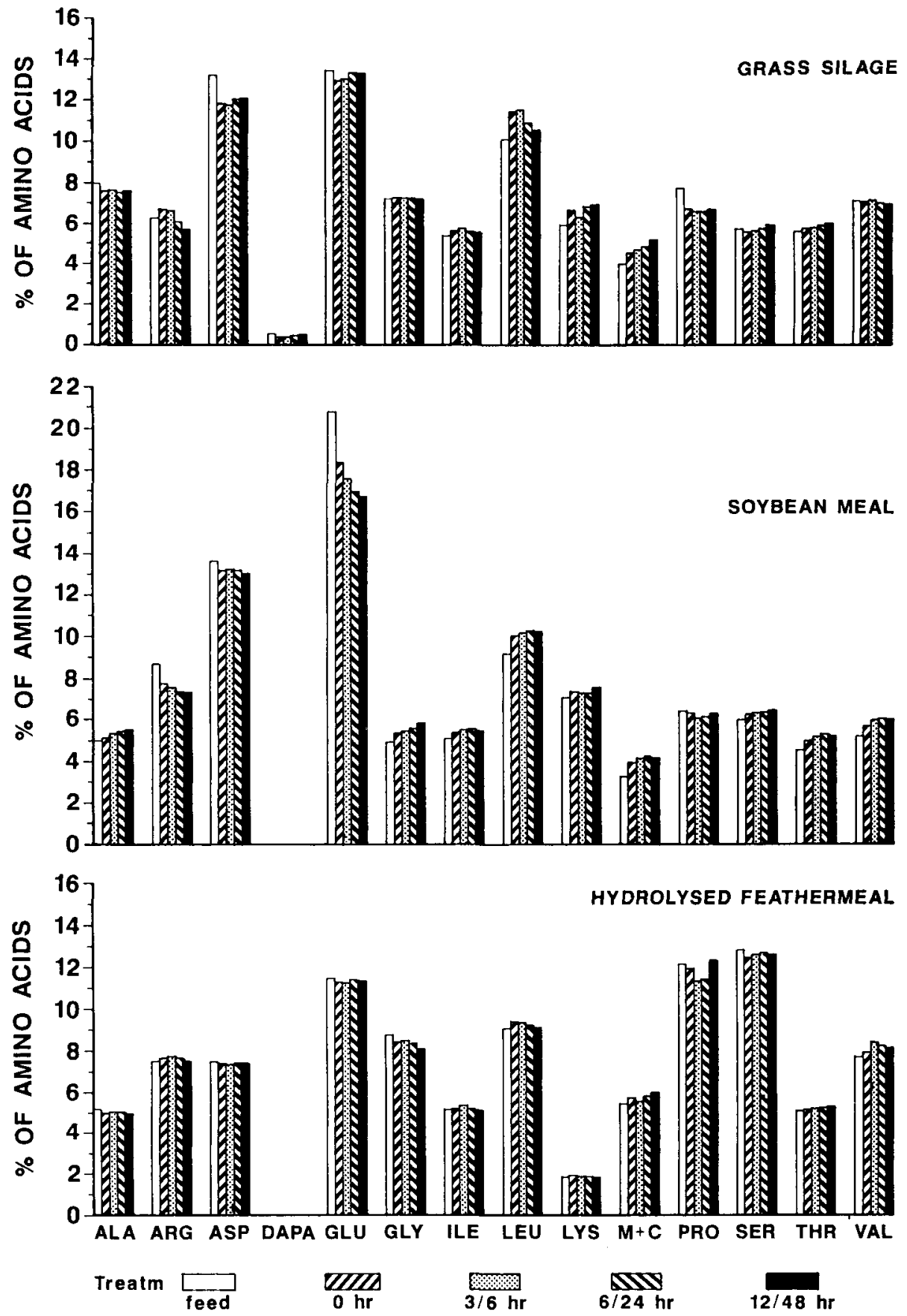

Fig. 1. Amino acid pattern in nylon bag residue. 
Table 2. Least square means of DAPA N (in \% of total amino acid $\mathrm{N}$ ) after incubation.

\begin{tabular}{ll}
\hline Incubation time $(\mathrm{h})$ & Mean $(\%)$ \\
0 & $0.352^{\mathrm{a}} 1$ \\
6 & $0.364^{\mathrm{a}}$ \\
24 & $0.420^{\mathrm{ab}}$ \\
48 & $0.448^{\mathrm{b}}$ \\
\hline
\end{tabular}

1 Significant differences are indicated by different letters.

Microbial contamination of the feed residue, based on DAPA concentration in the residues after incubation, seemed to become relatively more important with time of incubation, as it disappeared significantly slower from the nylon bags than the other amino acids (Table 2). Microbes were firmly attached to the feed because DAPA could only partly be removed by washing. After standard washing 55 and $14 \%$ of the original DAPA was still present in the fresh sample and the residue after $48 \mathrm{~h}$ incubation, respectively. For the washing procedures with ND at 25 and $70{ }^{\circ} \mathrm{C}$ these values were 32,9 and $40,8 \%$, respectively.

Soaking in ND at $25^{\circ} \mathrm{C}$ and at $70^{\circ} \mathrm{C}$ increased on average protein solubility in the original samples to 42.0 and $64.2 \%$ as compared to $16.2 \%$ after washing with water only. Hence, ND not only removed microbial contamination, it also solubilized part of the insoluble feed protein. This effect was significantly higher in soybean meal than in feathermeal. The effect on grass silage was intermediate. The rate $\left(k_{\mathrm{d}}\right)$ of protein degradation and amino acid release was not influenced by washing procedure.

\section{Conclusions}

- The profile of amino acid residue is almost exclusively determined by the original feed. Differences in rate of amino acid disappearance from nylon bags incubated in the rumen seem to exist, but are only of minor importance.

- Amino acids disappeared at a faster rate from the sample than non-amino acid $\mathrm{N}$, particularly in grass silage.

- The problem of microbial contamination appears to be restricted to feeds rich in cell wall constituents, because it was only observed in grass silage and not in soybean meal and feathermeal.

- DAPA-N in grass silage and its residues after incubation was not eliminated by washing in ND. ND at $25^{\circ} \mathrm{C}$ or $70^{\circ} \mathrm{C}$ not only reduced microbial contamination, but also solubilized part of the insoluble protein, especially in soybean meal.

\section{Acknowledgement}

Amino acids and DAPA content were determined by Degussa AG. 


\section{References}

CVB, 1988. Feedstuff table (In Dutch). Centraal Veevoederbureau in Nederland, Lelystad.

Crooker, B. A., J. H. Clark, R. D. Shanks \& G. J. Fahey Jr., 1987. Effect of ruminal exposure on the amino acid profile of feeds. Canadian Journal of Animal Science 67: 1143-1148.

Goering, H. K. \& P. J. van Soest, 1970. Forage fiber analyses. Agricultural Handbook No 379, ARS, USDA, Washington DC.

Mehrez, A. Z. \& E. R. Orskov, 1977. A study of the artificial fibre bag technique for determining the digestibility of feeds in the rumen. Journal of Agricultural Science (Cambridge) 88: 645-650.

Nicolic, A. J. \& M. Jovanovic, 1973. Preliminary study on the use of different methods for determining the proportion of bacterial nitrogen. Journal of Agricultural Science (Cambridge) 81: 1-7.

Nocek, J. E., 1987. In situ and other methods to estimate ruminal protein and energy digestibility: a review. Journal of Dairy Science 71: 2051-2069.

Rooke, J. A., H. A. Greife \& D. G. Amstrong, 1984. The effect of in sacco rumen incubation of a grass silage upon the total and D-amino acid composition of the residual silage dry matter. Journal of Agricultural Science (Cambridge) 102: 695-702.

Stadler, R. \& H. Tanner, 1984. Determination of methionine and cystine after oxidation with performic acid and hydrolysos. Journal of Agriculture and Food Chemistry 32: 1366-1371.

SAS, 1985. SAS User's Guide: Statistics, Version 5. Statistical Analysis System Inst., Cary NC, USA.

Soest, P. J. van, 1983. Nutritional ecology of the ruminant. O \& B Books, Inc., Oregon.

Tamminga, S., R. Ketelaar \& A. M. van Vuuren, 1989. Degradation of nitrogen in conserved forage in the rumen of dairy cows. Journal of Grass and Forage Science (in press).

Ullrich, B., 1984. Quantifizierung des mikrobiellen Protein-anteils in Silage mit Hilfe von ${ }^{15} \mathrm{~N}$ und Veränderungen im Aminosäuremunster bei unterschiedlichen Gärverlauf. Dissert. Univ. Hannover.

This synopsis is based on a student thesis entitled 'In sacco vertering van aminozuren bij koeien' by W. J. A. Kouwenberg, Department of Animal Nutrition, Wageningen Agricultural University, Wageningen, 1989, 40 pp., 12 tables, 7 figs, 29 refs, 2 apps, in Dutch, English summary. Available as paper copy (order R105, $f 10$, - including postage) at NARD, clo Pudoc, P.O. Box 4, 6700 AA Wageningen (telex 45015 bluwgnl). 